$\lim ^{\operatorname{RFP}-1096}$

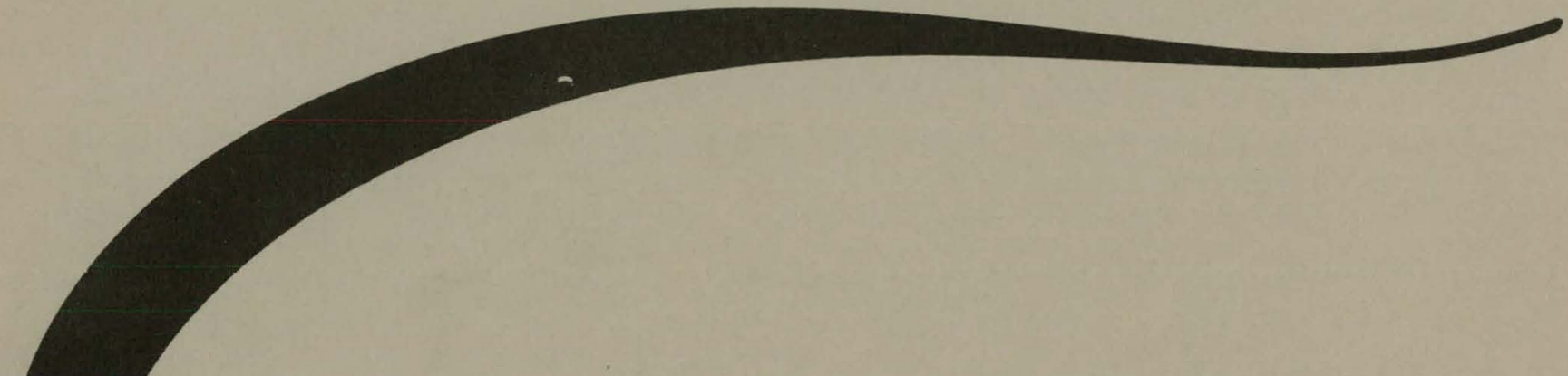

AIR GAGE FIXTURE FOR MEASUREMENT OF WORK-PIECE SEATING LOCATION

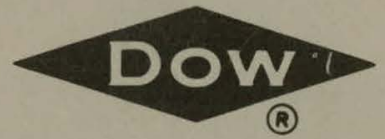

THE DOW CHEMICAL COMPANY ROCKY FLATS DIVISION

P. O. BOX 888

GOLDEN, COLORADO 80401

U.S. ATOMIC ENERGY COMMISSION

CONTRACT AT(29-1)-1106 


\section{DISCLAIMER}

This report was prepared as an account of work sponsored by an agency of the United States Government. Neither the United States Government nor any agency Thereof, nor any of their employees, makes any warranty, express or implied, or assumes any legal liability or responsibility for the accuracy, completeness, or usefulness of any information, apparatus, product, or process disclosed, or represents that its use would not infringe privately owned rights. Reference herein to any specific commercial product, process, or service by trade name, trademark, manufacturer, or otherwise does not necessarily constitute or imply its endorsement, recommendation, or favoring by the United States Government or any agency thereof. The views and opinions of authors expressed herein do not necessarily state or reflect those of the United States Government or any agency thereof. 


\section{DISCLAIMER}

Portions of this document may be illegible in electronic image products. Images are produced from the best available original document. 


\section{LEG AL NOTICE}

This report was prepared as an account of Government sponsored work. Neither the United States, nor the Commission, nor any person acting on behalf of the Commission:

A. Makes any warranty or representation, expressed or implied, with respect to the accuracy, completeness, or usefulness of the information contained in this report, or that the use of any information, apparatus, method, or process disclosed in this report may not infringe privately owned rights; or

B. Assumes any liabilities with respect to the use of, or for damages resulting from the use of any information, apparatus, method, or process disclosed in this report.

As used in the above, "person acting on behalf of the Commission" includes any employee or contractor of the Commission, or employee of such contractor, to the extent that such employee or contractor of the Commission, or employee of such contractor prepares, disseminates, or provides access to, any information pursuant to his employment or contract with the Commission, or his employment with such contractor.

Printed in the United States of America Available from

Clearinghouse for Federal Scientific and Technical Information National Bureau of standards, U. S. Deparlment of Commerce Springfield, Virginia 22151

Price: Printed Copy $\$ 3.00$; Microfiche $\$ 0.65$ 


\section{AIR GAGE FIXTURE FOR MEASUREMENT OF WORK-PIECE SEATING LOCATION}

R. A. Larson

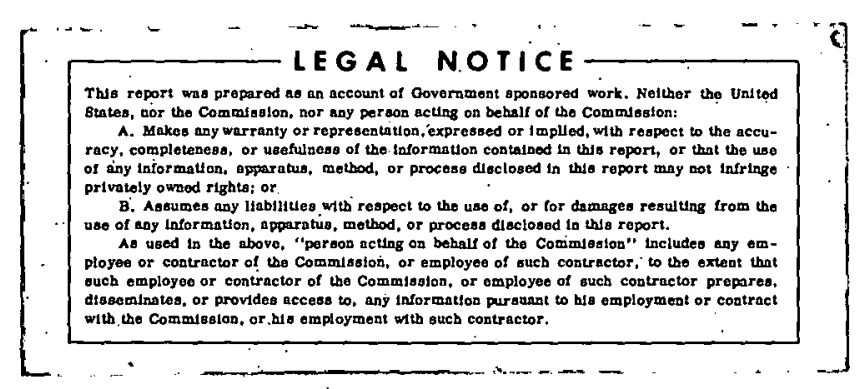

THE DOW CHEMICAL COMPANY ROCKY FLATS DIVISION.

P. O. BOX 888 GOLDËN, COLORADO 80401

U. S. ATOMIC ENERGY 'COMMISSION CONTRACT AT(29-1)-1106 


\title{
AIR GAGE FIXTURE FOR MEASUREMENT OF WORK-PIECE SEATING LOCATION
}

\author{
R. A. Lars on
}

Abstract. An open air-jet mounted in a workholding fixture will measure the work-piece seating location prior to machining. Machine-tool compensations can then be made to eliminate finalproduct error due to inconsistent seating of parts as illustrated in Figure 1.

\section{DISCUSSION}

Figure 2 illustrates a vacuum holding-fixture fitted with an air gage. The part location (dimension A) is measured for each part, and machinetool settings are changed as required to eliminate final-part errors either from a face or insidecontour machining operation. Dimension A should be checked after the machining operation to determine part-location changes which may have occurred during the machining operation.

The air-gage fixture uses a no contact, open, air-jet nozzle (Figure 3 ) press-fitted into the base of the fixture. The air-jet gaging surface is finished to the contour of the work-holding fixture.
For gaps of zero to 0.0025 inches the accuracy of the system is compatible with open jet-nozzle applications; that is, with in \pm 0.0001 inch accuracy .

The drift of the air-gage readout can be checked on the machine by stopping the flow at the open jet, or at the air gage readout plug, either of which will give a 0.0001 inch lower reading than a part bottomed out in the fixture. The magnification of the readout system should bc checked (and originally set) off the machine using a calibration fixture which is shown in Figure 4. The calibration fixture can be used for size and shape of the work holding fixture so long as the detail dimensions of the air gage' (Figure 3 ) are used in the fixture design.

Eight to ten additional man hours are required to add the air gage feature to a new fixture. The rcadout system is calibrated in one hour, and on-the-machine readings of part location take 15 sec onds or less.

FIGURE 1. Work-holding fixture without air gage. Although the outside contour is within specifications, the seating variance is great enough to cause scrap during the inside-contour finishing operation.

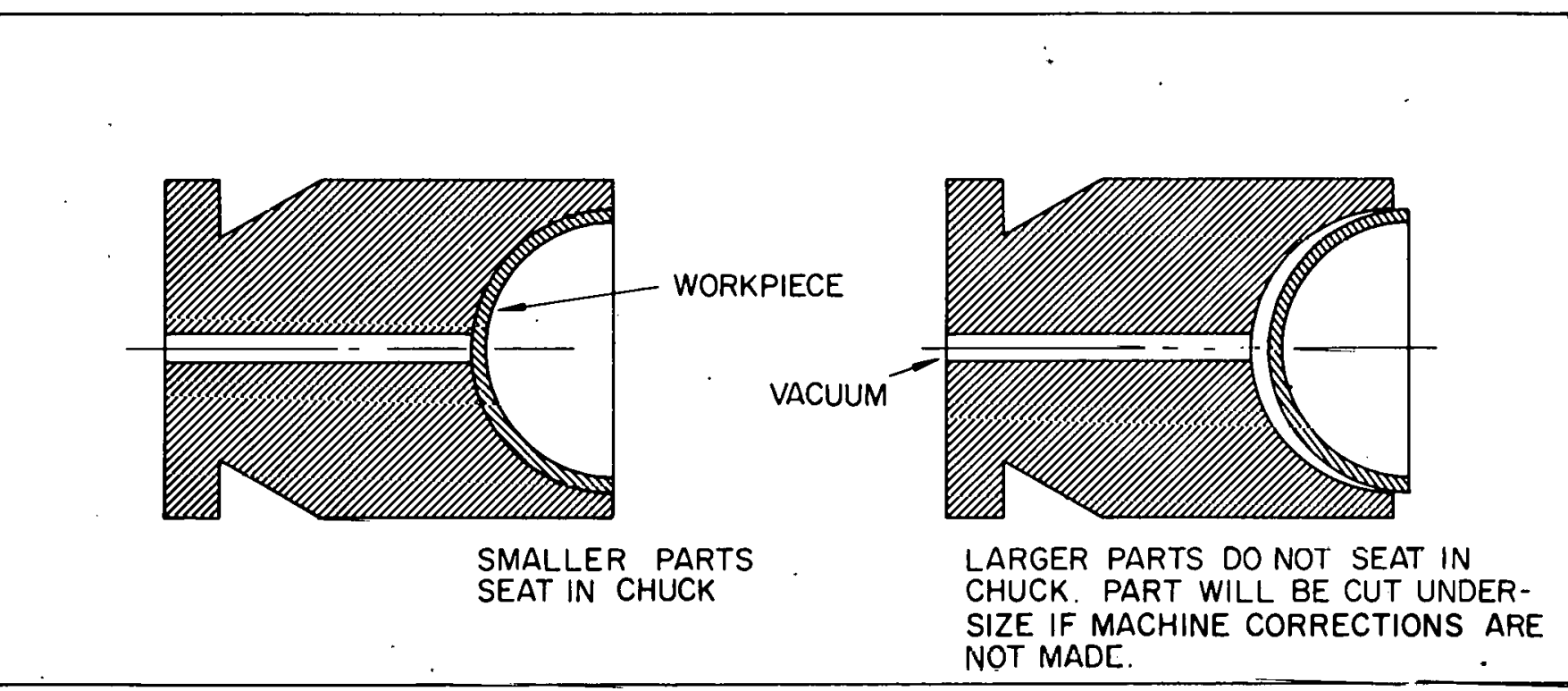




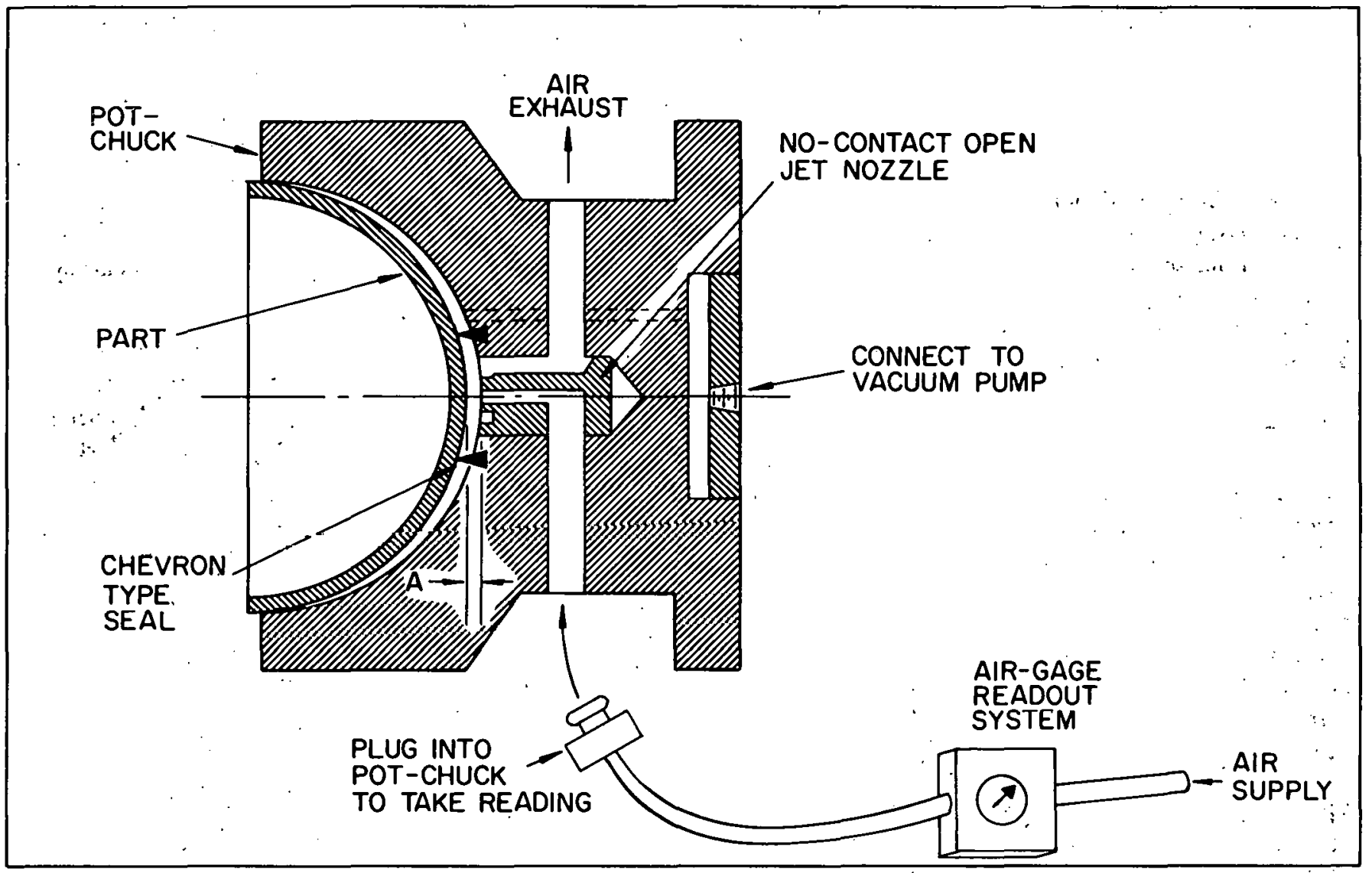

FIGURE 2. Work-holding fixture with air gage. The interaction of the open air-jet and the part results in a back pressure proportional to dimension $A$, which is then measured in terms of distance by a commercial readout system with adjustable magnification:

FIGURE 3. Delail drawing of air-jet nozzle. All jets must. be made to same dimensions to ensure correct calibration of air-gage readout system.
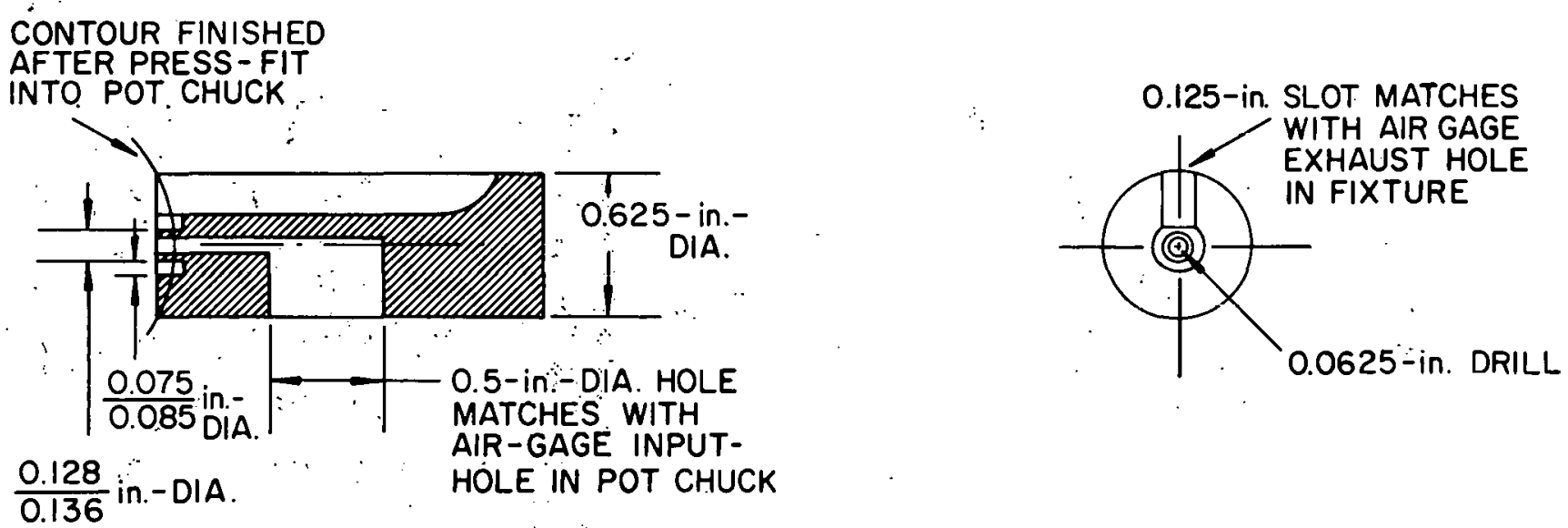
(a)

(b)
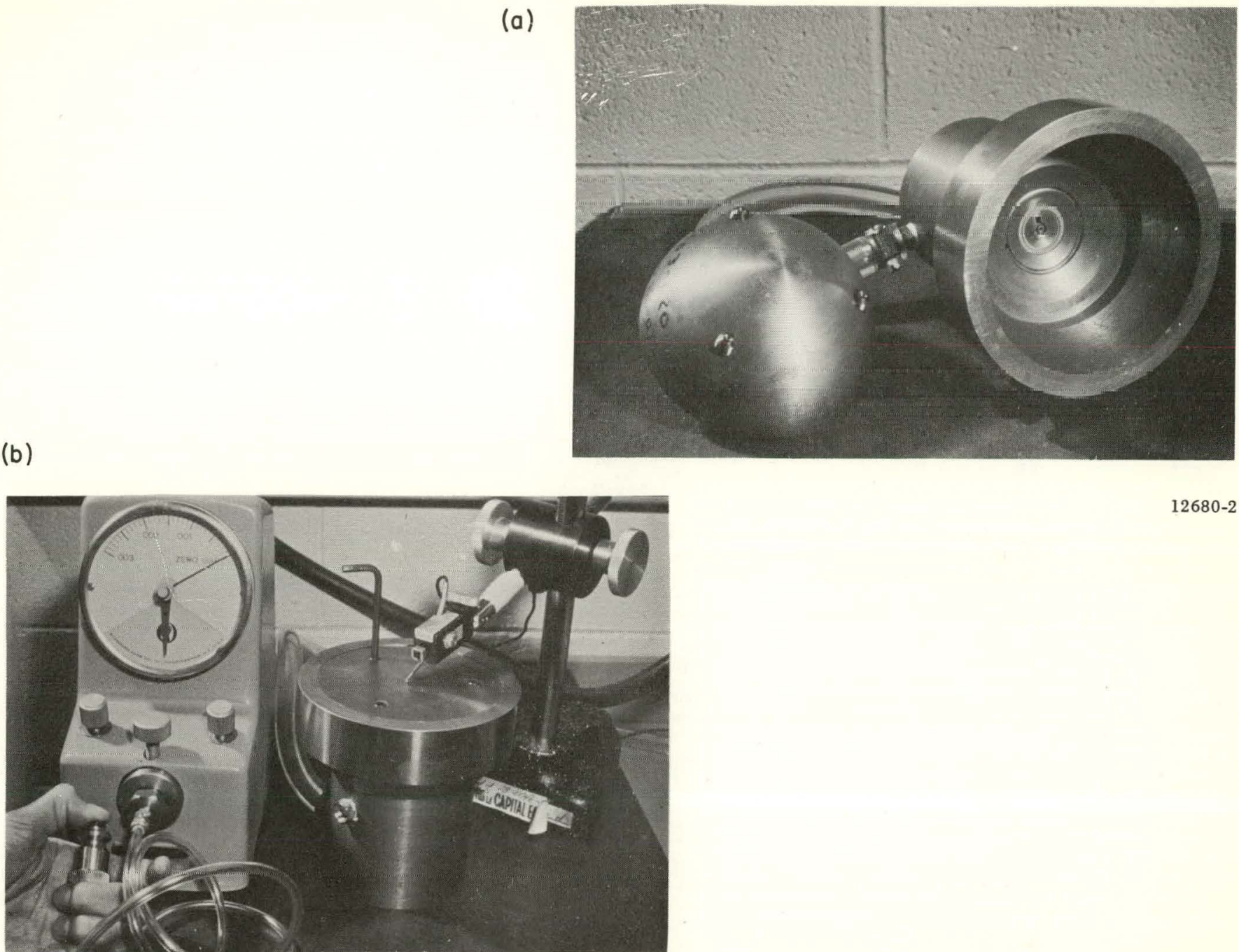

$12680-2$

$12680-7$

(c)

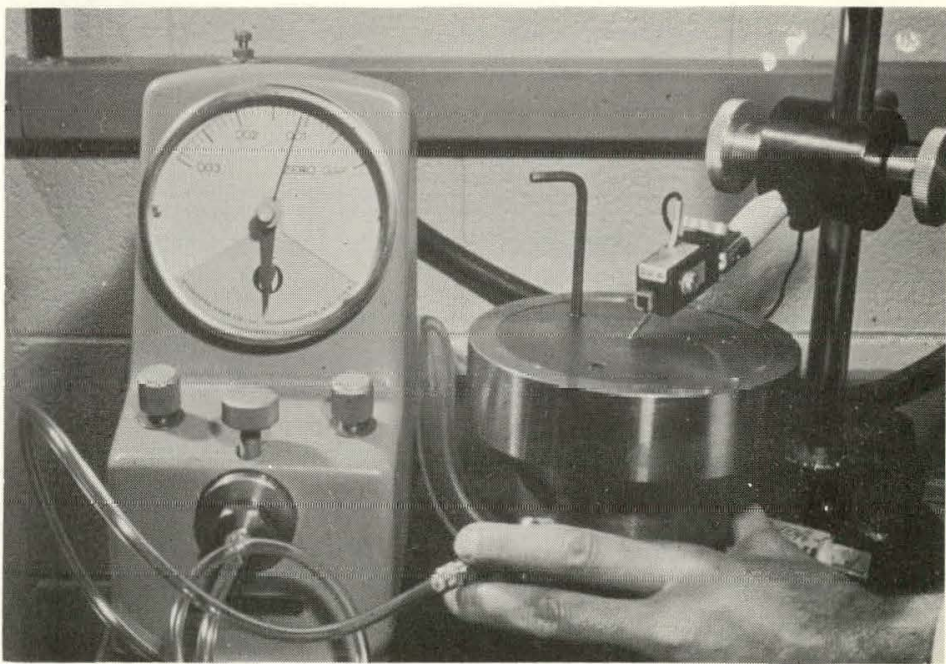

FIGURE 4. Special fixture necessary to calibrate air gage system. (a) Calibration part and fixture, (b) plugging the output of the air gage readout system yields 0.0001 inch lower reading than a fully seated part, (c) when the calibration part is raised 0.001 inch, the readout system is set to read 0.001 inch. 